\title{
Witches'-Broom Disease of Lime Affects Seed Germination and Seedling Growth But Is Not Seed Transmissible
}

M. M. Faghihi, A. N. Bagheri, H. R. Bahrami, H. Hasanzadeh, and R. Rezazadeh, Hormozgan Agriculture and Natural Resources Research Center, Iran; M. Siampour, Department of Plant Protection, College of Agriculture, Shiraz University, Shiraz, Iran; S. Samavi, Hormozgan Agriculture and Natural Resources Research Center, Iran; M. Salehi, Fars Agriculture and Natural Resources Research Center, Iran; and K. Izadpanah, Department of Plant Protection, College of Agriculture, Shiraz University, Shiraz, Iran

\begin{abstract}
Faghihi, M. M., Bagheri, A. N., Bahrami, H. R., Hasanzadeh, H., Rezazadeh, R., Siampour, M., Samavi, S., Salehi, M., and Izadpanah, K. 2011. Witches'-broom disease of lime affects seed germination and seedling growth but is not seed transmissible. Plant Dis. 95:419-422.

Witches'-broom disease of lime (WBDL), caused by 'Candidatus Phytoplasma aurantifolia', has devastated many Mexican lime orchards and is currently a threat to lime production in neighboring provinces of southern Iran. Several reports have suggested transmission and spread of WBDL phytoplasma through the seed of infected plants. In the present study, claims of seed transmission of this phytoplasma were examined. Fruit were collected from infected trees in the infested areas of Minab (Hormozgan Province) and from symptomless trees in noninfested areas. Lime seed from symptomless and witches'-broomaffected trees were sown in separate beds in an insect-proof screenhouse and the resulting seedlings were examined for phytoplasmal infection. Leaf, stem, and root samples were collected from both groups of seedlings every 3 months for 2 years and tested for WBDL

Repeated PCR tests on the seedlings did not reveal the presence of phytoplasmal DNA. Likewise, symptoms of the disease were not observed on these seedlings after 2 years. PCR assays detected the phytoplasma in coats of some seed from infected trees; however, no excised embryos were positive for the phytoplasma. All positive PCR results were confirmed by restriction fragment length polymorphism assay. One-year-old seedlings derived from seed of noninfected plants appeared more vigorous in terms of height, number of leaves, and fresh weight of shoot compared with those from infected trees. The germination percentage, mean daily germination, peak value, and germination value were significantly higher for seed of fruit from noninfected trees and seed from fruit on asymptomatic branches of infected trees than those from fruit on symptomatic branches of infected trees.
\end{abstract} phytoplasma using direct and nested polymerase chain reaction (PCR).
Witches'-broom disease of lime (WBDL), caused by 'Candidatus Phytoplasma aurantifolia' was found first in a small area in southern Iran in 1997 (17). Since then, WBDL has spread to many areas, devastating Mexican lime plantations in major lime-growing provinces of Hormozgan, Sistan-Baluchistan, and Kerman (16). In the field, the phytoplasma is naturally spread by the vector leafhopper Hishimonus phycitis (18). The pathogen has been experimentally transmitted to several species of citrus by graft inoculation, and to periwinkle and a number of solanaceous plants such as tomato, eggplant, and tobacco by dodder or graft inoculation (1921). Several studies have focused on the detection of WBDL phytoplasma in various parts of the lime seed. El-Kharbotly et al. (5) were the first to suggest the possibility of seed transmission of WBDL phytoplasma. Later, Khan (9) used the polymerase chain reaction (PCR) assay to study seed transmission of WBDL phytoplasma in 6-month-old seedlings. Based on this report, the majority of seed from infected plants in Oman yielded infected seedlings. The author also reported the presence of phytoplasma-like structures in seed tissues by electron microscopy. Such a high rate of seed transmission is unusual for a phloem-limited organism. Our observation in affected citrus groves of southern Iran does not support seed transmissibility of this phytoplasma. On the other hand, there is no information on the effect of phytoplasmal infection of lime trees on the viability of seed and growth of seedlings from fruit from infected trees. Lime trees in southern Iran are mainly propagated through seed. In addition, lime seedlings are used as rootstock for many citrus species and cultivars. Therefore, the issue

Corresponding author: K. Izadpanah, E-mail: Izadpana@shirazu.ac.ir

Accepted for publication 16 November 2010.

doi:10.1094/PDIS-06-10-0400

(C) 2011 The American Phytopathological Society of seed transmissibility of ' $\mathrm{Ca}$. Phytoplasma aurantifolia' must be clarified because it relates directly to the implementation of control strategies. In the present study, we evaluated the effect of WBDL infection on certain horticultural parameters of lime seed, presence of the phytoplasma in seed tissues, and seed transmission of the WBDL phytoplasma.

\section{Materials and Methods}

Seed collection, sowing, germination, and sampling. Fruit were harvested at commercial maturity from severely infected trees (Fig. 1A and B) in the Minab region and from noninfected trees in noninfested areas of Hormozgan Province, Iran, and seed were manually extracted. Approximately 6,000 seeds from infected and healthy trees, respectively, were sown in field soil in separate 2.5 by-10-m beds in a leafhopper-proof screenhouse at the Minab Agricultural Research Station in September 2007. Seedlings were observed weekly for abnormalities and sampled for PCR assays every 3 months over a period of 2 years. Leaves, stems, and roots from 75 randomly selected seedlings were subjected to DNA extraction followed by direct and nested PCR to detect phytoplasma. In another experiment to facilitate germination of all embryos, 30 seeds from infected plants and 10 seeds from noninfected plants were surface sterilized with $1 \%$ sodium hypochlorite, rinsed three times with sterile distilled water, and cultured ( 2 seeds per tube) on half-strength Murashige-Skoog basal salts (12) for 2 to 4 weeks. All seedlings were then tested using direct and nested PCR.

DNA extraction. Total DNA was extracted from lime tissues using a modified cetyltrimethylammonium bromide (CTAB) procedure (4) as follows. Approximately 0.3 to $0.5 \mathrm{~g}$ of either leaf midrib, root, or crown tissue was powdered in liquid nitrogen, transferred to $1.5-\mathrm{ml}$ centrifuge tubes, and mixed with $700 \mu \mathrm{l}$ of hot $\left(60\right.$ to $\left.65^{\circ} \mathrm{C}\right) \mathrm{CTAB}$ buffer $(20 \mathrm{mM}$ EDTA, $100 \mathrm{mM}$ Tris- $\mathrm{HCl}$ [pH 80], 2\% CTAB, $1.4 \mathrm{M} \mathrm{NaCl}, 1 \%$ polyvinyl pyrrolidone, and $0.2 \% 2$-mercaptoethanol in sterile distilled water). The homogenate was incubated at 60 to $65^{\circ} \mathrm{C}$ for $1 \mathrm{~h}$ with gentle inversion every 15 
min, then extracted with $700 \mu \mathrm{l}$ of chloroform/iso-amyl alcohol (24:1). The mixture was centrifuged (Eppendorf centrifuge 5415 R) at $12,000 \mathrm{rpm}(13,400 \times \mathrm{g})$ for $10 \mathrm{~min}$ and the supernatant was transferred to a fresh microcentrifuge tube. DNA was precipitated by adding 0.7 volume of cold isopropanol and the mixture was incubated for $30 \mathrm{~min}$ at $-20^{\circ} \mathrm{C}$ and centrifuged for $10 \mathrm{~min}$ at $13,000 \mathrm{rpm}(15,700 \times g)$. The supernatant was removed and the pellet was washed three times with $200 \mu \mathrm{l}$ of $70 \%$ ethanol and centrifuged for $5 \mathrm{~min}$ at $5,000 \mathrm{rpm}(2,300 \times g)$. The pellet was dried, dissolved in $100 \mu \mathrm{l}$ of Tris-EDTA buffer $(10 \mathrm{mM}$ Tris and 1 mM EDTA, $\mathrm{pH}$ 8.0) or sterile double-distilled water and stored at
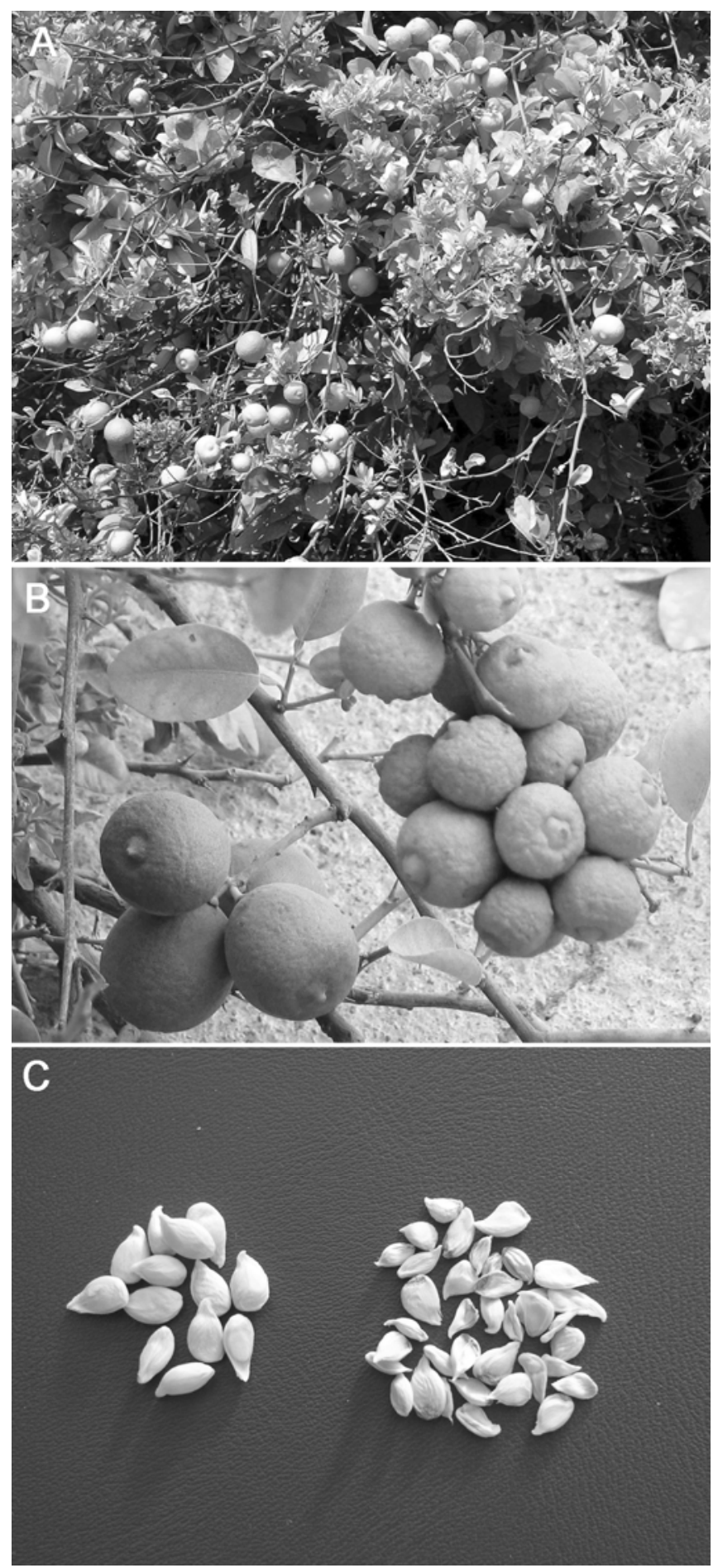

Fig. 1. Effect of witches'-broom disease of lime (WBDL) phytoplasma infection on fruit and seed of Mexican lime. A, Fruit on a WBDL-infected Mexican lime tree; B, fruit aggregates on symptomatic branches of an infected tree; $\mathbf{C}$, seed from symptomatic fruit of infected tree (right) compared with those from noninfected trees (left). $-20^{\circ} \mathrm{C}$. DNA was separately extracted from whole seed $(50$ samples of 3 seeds/sample; 150 seeds total), seed coats from infected plants (10 samples of 3 seeds/sample; 30 seeds total), and 600 excised embryos (three lots of 200 embryos each) from the seed of infected trees. DNA was extracted from the powdered tissues following the above-mentioned procedure (4) after grinding seed or seed parts in liquid nitrogen.

PCR. Both direct and nested PCR were performed to detect the phytoplasma in various tissues. Each reaction mixture of $20 \mu \mathrm{l}$ contained $13 \mu \mathrm{l}$ of $\mathrm{H}_{2} \mathrm{O}, 2 \mu \mathrm{l}$ of $10 \times$ PCR buffer, $1.2 \mu \mathrm{l}$ of $\mathrm{MgCl}_{2}$ (25 mM), $0.4 \mu \mathrm{l}$ of each dNTP $(10 \mu \mathrm{M}), 1.25 \mathrm{U}$ of Taq DNA polymerase (Cinagen, Iran), $1 \mu \mathrm{l}$ of each oligonucleotide primer (100 $\mu \mathrm{M}$ ), and 20 to $30 \mathrm{ng}$ of genomic DNA template. Universal primer pair P1/P7 (22) was used to amplify a fragment of $1,800 \mathrm{bp}$ of ribosomal operon that extended from the $5^{\prime}$ end of $16 \mathrm{~S}$ rRNA to the $5^{\prime}$ region of the $23 \mathrm{~S}$ rRNA gene. Amplification was carried out with an initial denaturing temperature of $94^{\circ} \mathrm{C}$ for $2 \mathrm{~min}$; followed by 35 cycles of $94^{\circ} \mathrm{C}$ for $1 \mathrm{~min}, 56^{\circ} \mathrm{C}$ for $1 \mathrm{~min}$, and $72^{\circ} \mathrm{C}$ for $2 \mathrm{~min}$; and a final extension cycle at $72^{\circ} \mathrm{C}$ for $10 \mathrm{~min}$. To increase the sensitivity of assays, nested PCR was performed using primer pairs R16F2n/R16R2 (6) with 1:20 dilution of P1/P7 primed PCR products as template. The thermocycling program consisted of an initial denaturing step for $3 \mathrm{~min}$ at $95^{\circ} \mathrm{C}$; followed by 35 cycles of $94^{\circ} \mathrm{C}$ for $30 \mathrm{~s}, 55^{\circ} \mathrm{C}$ for $30 \mathrm{~s}$, and $72^{\circ} \mathrm{C}$ for $2 \mathrm{~min}$; and a final extension cycle at $72^{\circ} \mathrm{C}$ for $10 \mathrm{~min}$. Each PCR product $(10 \mu \mathrm{l})$ was analyzed by electrophoresis in a $1 \%$ agarose gel in $1 \times$ Tris-borate-EDTA buffer. PCR products were visualized on $1 \%$ agarose gels stained with ethidium bromide. In each experiment, the symptomatic leaves of infected lime were included as positive controls and leaves of noninfected plants and sterile distilled water were used as negative controls.

Restriction fragment length polymorphism. Samples yielding visible DNA bands after PCR were examined by restriction fragment length polymorphism (RFLP). The PCR product was digested by restriction enzymes AluI, HhaI, HpaII, RsaI, and TaqI (Roche, Germany) following the manufacturer's instructions. Usually, $8 \mu \mathrm{l}$ of PCR product was digested for $4 \mathrm{~h}$ at $37^{\circ} \mathrm{C}\left(65^{\circ} \mathrm{C}\right.$ for TaqI) in a $20-\mu \mathrm{l}$ reaction volume using 1 unit of each enzyme. Digested products were separated on $2 \%$ agarose gels and stained with ethidium bromide.

Seed germination parameters and vegetative growth of seedlings. Four replicates of 100 seeds from each healthy and infected tree were placed on wet filter paper in petri dishes in an incubator at $25^{\circ} \mathrm{C}$ with $16 \mathrm{~h}$ of light and $8 \mathrm{~h}$ of darkness. Seed originating from symptomatic and symptomless branches of infected trees were tested separately. The data on seed germination was recorded daily as germinated or nongerminated seed up to 37 days and, at the completion of the test, germination percentage (GP), mean daily germination (MDG), peak value of germination (PV), and germination value $(\mathrm{GV})$ were calculated (7). GP is the percentage of germinated seed at the end of the germination period, while GV is an index, combining both speed and completeness of germination. GP and GV eliminate the need of subjective value judgment. and can be expressed as GV= MDG $\times \mathrm{PV}$, where MDG is the number of germinated seed divided by the number of days at the end of examination and PV is the daily cumulative percent germination divided by days since the start of the test (3). Weights of 1,000 seeds originating from noninfected trees, asymptomatic branches of infected trees, or symptomatic branches of infected trees were compared by weighing four samples of 300 seeds each, and extrapolating the means to 1,000 seeds. To compare the vegetative growth of seedlings derived from seed of severely infected plants to those derived from seed of asymptomatic plants, 100 1-year-old seedlings from each source were randomly removed and several parameters of seedling vigor, including plant height, stem diameter, internode length, number of leaves, length and width of leaves, shoot fresh weight, and root fresh weight were measured after 1 year and means were compared using Tukey's test.

\section{Results}

Phytoplasmal assay. Witches'-broom symptoms were not observed on the approximately 6,000 seedlings grown from seed of 
infected or healthy trees after 2 years. PCR analysis of leaf, stem, and root tissues of 600 samples did not detect any phytoplasmapositive samples. None of the in vitro-grown plantlets from seed of infected trees showed symptoms or were positive by PCR. Direct and nested PCR detected WBDL phytoplasma in 20 and 34\%, respectively, of seed samples from infected trees. Neither direct nor nested PCR detected phytoplasma in the excised embryos, seedlings, and in vitro-grown seedlings from seed of infected trees (Table 1). The rates of phytoplasma detection in whole seed, seed without embryos, and seed coats were similar, indicating confinement of the phytoplasma to the seed coats. Although the WBDL phytoplasma was detected in seed harvested from infected trees, seed transmission of WBDL to seedlings was not observed. In all cases of positive PCR, the RFLP pattern was the same as that for ' $C a$. Phytoplasma aurantifolia' (11; Fig. 2).

Seed size, seed germination parameters, and vigor of resulting seedlings. Seed from symptomatic fruit on witches'-broom branches of infected trees showed some necrosis of the seed coat and were smaller than the seed from nonsymptomatic branches of infected trees and those from noninfected trees (Fig. 1C). In all, 1,000 seeds from symptomatic fruit on witches'-broom branches of infected trees weighed $16.2 \pm 0.2 \mathrm{~g}$ compared with $29.3 \pm 0.3 \mathrm{~g}$ for seed of fruit on normal branches and $33.1 \pm 0.9 \mathrm{~g}$ for seed from noninfected trees. Compared with seed from symptomatic branches of infected trees, seed from asymptomatic branches of infected trees and normal plants showed significantly $(P<0.01)$ higher GPs, MDG, PV, and GV. No significant differences were observed at $P<0.01$ in the germination parameters between seed from fruit on asymptomatic branches of infected trees and those from normal trees (Table 2). There were no significant differences in vegetative growth parameters such as crown diameter, internode length, leaf length, leaf width, and fresh weight of root in 1-year-old seedlings derived from seed of normal trees and those derived from seed of infected trees (Table 3). Significant differences at $P<0.01$ in plant height and leaf number were observed between the seedlings derived from symptomatic and nonsymptomatic branches (Table 3). One-year-old seedlings from seed of infected plants had fewer shoots, lower fresh weight, and lower plant height.

\section{Discussion}

Seed transmission of phytoplasmas is a matter of controversy. Some researchers dispute seed transmission of these phloem-limited organisms because of the absence of direct connection between sieve elements and embryos (10). Phytoplasmal seed transmission has recently been reported in tomato, oilseed rape, and lime plantlets by Botti and Bertaccini (1). Others have shown the presence of phytoplasmas in seed coat or even in the embryo of affected plants with no concrete evidence of phytoplasma passage into seedlings $(2,13-15)$. However, one cannot absolutely rule out seed transmission of phytoplasmas when these organisms infect seed embryos. Although lime trees are propagated by seed in southern Iran and seedlings of lime and several other citrus species are highly susceptible to WBDL infection by graft inoculation (20), symptoms of the disease have seldom been observed in lime seedlings or young plants in affected areas. Furthermore, examination of many field-grown seedlings by PCR has shown no indication of their infection. Based on our results, we conclude that seed transmission of WBDL phytoplasma does not occur in lime.

Our results show that WBDL phytoplasma may be detected in seed of infected plants but is confined to the seed coats. These results are in agreement with the findings of Jiang et al. (8), who used direct and nested PCR to detect mulberry dwarf (MD) phytoplasma in seed coats but not in seed embryos of MD-affected mulberry. No symptoms of the disease were observed in the resulting seedlings from seed of infected mulberry and seed transmission of this disease did not occur (8).

Contrary to our findings with WBDL, the European stone fruit yellowing (ESFY) phytoplasma was detected in the seed embryos of stone fruit, and such infected seed showed very low viability

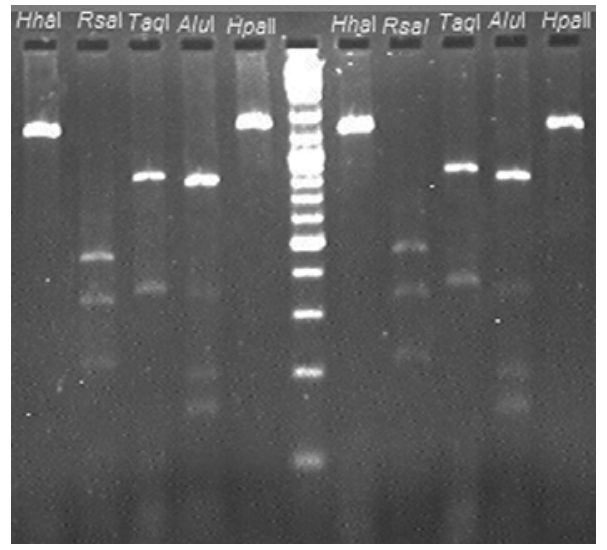

Fig. 2. Restriction fragment length polymorphism analysis of polymerase chain reaction products from a witches'-broom disease of lime (WBDL)-infected lime seed coat (left) and WBDL-positive control (right). $M$ is DNA marker.

Table 2. Germination parameters of seed from infected (symptomatic and asymptomatic branches) and noninfected trees

\begin{tabular}{|c|c|c|c|}
\hline \multirow[b]{3}{*}{$\begin{array}{l}\text { Germination } \\
\text { parameters }^{\mathrm{z}}\end{array}$} & \multicolumn{3}{|c|}{ Seed source ${ }^{\mathrm{y}}$} \\
\hline & \multirow[b]{2}{*}{$\begin{array}{c}\text { Noninfected } \\
\text { trees }\end{array}$} & \multicolumn{2}{|c|}{ Infected trees } \\
\hline & & $\begin{array}{c}\text { Asymptomatic } \\
\text { branches }\end{array}$ & $\begin{array}{c}\text { Symptomatic } \\
\text { branches }\end{array}$ \\
\hline GP & $92.0 \mathrm{a}$ & $92.0 \mathrm{a}$ & $80.0 \mathrm{~b}$ \\
\hline MDG & $3.1 \mathrm{a}$ & $3.0 \mathrm{a}$ & $2.2 \mathrm{~b}$ \\
\hline PV & $3.2 \mathrm{a}$ & $3.1 \mathrm{a}$ & $2.6 \mathrm{~b}$ \\
\hline GV & $9.9 \mathrm{a}$ & $9.3 \mathrm{a}$ & $5.7 \mathrm{~b}$ \\
\hline
\end{tabular}

${ }^{\mathrm{y}}$ Means with the same letter in each row are not significantly different at $P$ $<0.01$ using Tukey's test.

${ }^{\mathrm{z}} \mathrm{GP}=$ Germination percentage, $\mathrm{MDG}=$ Mean daily germination, $\mathrm{PV}=$ peak value, and $\mathrm{GV}=$ germination value

Table 1. Direct and nested polymerase chain reaction (PCR) detection of Witches'-broom disease of lime phytoplasma in whole seed, seed coats, embryos, and seedlings originated from infected and noninfected Mexican lime trees

\begin{tabular}{|c|c|c|c|c|}
\hline \multirow[b]{2}{*}{ Samples } & \multirow[b]{2}{*}{ Origin } & \multirow[b]{2}{*}{ No of samples } & \multicolumn{2}{|c|}{ No of detections } \\
\hline & & & Direct PCR & Nested PCR \\
\hline Seed & Infected trees & 50 (3 seeds each) & $10(20 \%)$ & $17(34 \%)$ \\
\hline Excised embryos & Seed from infected trees & 3 (200 embryos each) & 0.0 & 0.0 \\
\hline Seed without embryos & Infected trees & 10 (3 seeds each) & $2(20 \%)$ & $4(40 \%)$ \\
\hline Seed endosperms & Infected trees & 10 (5 endosperms each) & 0.0 & 0.0 \\
\hline Seed coats & Infected trees & $6(10$ seeds each $)$ & $1(16.6 \%)$ & $2(33 \%)$ \\
\hline Seedlings & Seed from infected trees & 600 & 0.0 & 0.0 \\
\hline In vitro-grown seedlings & Seed from infected trees & 15 & 0.0 & 0.0 \\
\hline Seed & Noninfected trees & 10 (1-2 seeds each) & 0.0 & 0.0 \\
\hline Seedlings & Seed from noninfected trees & 60 & 0.0 & 0.0 \\
\hline Seed coats & Noninfected trees & 2 (10 seeds each) & 0.0 & 0.0 \\
\hline In vitro-grown seedlings & Seed from noninfected trees & 3 & 0.0 & 0.0 \\
\hline
\end{tabular}


Table 3. Vegetative growth parameters of seedlings derived from seed of infected and noninfected trees ${ }^{\mathrm{z}}$

\begin{tabular}{|c|c|c|c|c|c|c|c|c|}
\hline Seed source & $\begin{array}{c}\text { Plant } \\
\text { height }(\mathbf{c m})\end{array}$ & $\begin{array}{c}\text { Crown diameter } \\
(\mathbf{m m})\end{array}$ & $\begin{array}{c}\text { Internode } \\
\text { length }(\mathrm{cm})\end{array}$ & $\begin{array}{l}\text { No. of } \\
\text { leaves }\end{array}$ & $\begin{array}{l}\text { Leaf length } \\
\quad(\mathrm{mm})\end{array}$ & $\begin{array}{l}\text { Leaf width } \\
\quad(\mathrm{mm})\end{array}$ & $\begin{array}{c}\text { FW shoot } \\
\text { (g) }\end{array}$ & $\begin{array}{c}\text { FW root } \\
\text { (g) }\end{array}$ \\
\hline Noninfected trees & $60.9 \mathrm{a}$ & $3.4 \mathrm{a}$ & $15.1 \mathrm{a}$ & $39.4 \mathrm{a}$ & $46.8 \mathrm{a}$ & $26.8 \mathrm{a}$ & $8.4 \mathrm{a}$ & $0.9 \mathrm{a}$ \\
\hline Infected trees & $46.7 \mathrm{~b}$ & $3.3 \mathrm{a}$ & $15.3 \mathrm{a}$ & $30.4 \mathrm{~b}$ & $46.8 \mathrm{a}$ & $26.6 \mathrm{a}$ & $6.5 \mathrm{~b}$ & $0.9 \mathrm{a}$ \\
\hline
\end{tabular}

${ }^{\mathrm{z}} \mathrm{FW}=$ fresh weight. Means with the same letter in each column are not significantly different at $P<0.05$ or, for number of leaves and plant height, at $P<$ 0.01 using Tukey's test.

(21.6\%) and poor GP (9.4\%). However, similar to WBDL phytoplasma, transmission of ESFY phytoplasma via flower structures and seed has not yet been proven (13). As opposed to WBDL phytoplasma, Nipah et al. (14) detected Cape Saint Paul wilt disease (CSPWD) phytoplasma in seed embryos of West African Tall palms infected with CSPWD. Moreover, Cordova et al. (2) reported the presence of lethal yellowing phytoplasma in seed embryos from infected coconut trees. Nevertheless, as in WBDL phytoplasma, seed transmission of the two mentioned disease agents was reported to be unlikely.

Fruit were rarely observed on symptomatic branches of WBDLinfected trees. However, unusual aggregates of small, deformed fruit were occasionally seen on symptomatic branches (Fig. 1B). Seed coats derived from such fruit showed necrotic spots. The average weight of seed from fruit of symptomatic branches was $50 \%$ less than those from fruit of asymptomatic branches of infected and normal trees. Our results showed that the germination value of lime seed obtained from healthy trees is nearly 1.7 times higher than the seed of symptomatic fruit on WBDL phytoplasmapositive trees, whereas GP of seed from normal plants was only 1.2 times higher than the seed of symptomatic fruit of infected trees. Thus, the majority (80\%) of the seed obtained from fruit on symptomatic branches of infected plants were viable. Moreover, the seed of the fruit on symptomless branches of infected trees germinated as well as the seed of normal trees. There were also no significant differences in other germination parameters between seed from uninfected trees and those from asymptomatic branches of infected trees. This may be due to uneven distribution of the phytoplasma in the newly infected plants. The presence of WBDL phytoplasma in the embryos and seedlings derived from seed of infected lime has been reported $(1,9)$, although production of witches'-broom trees from such seed has never been demonstrated.

In the present study, we were not able to detect phytoplasmal DNA in any seedlings or plantlets derived from seed of infected trees. We also did not observe any symptomatic plants among several thousand seedlings from seed of infected trees grown under controlled condition in the present study. These findings are in accordance with the scarcity of WBDL-infected seedlings or young trees in affected plantations of southern Iran. Our conclusion that WBDL is not seed transmissible in southern Iran could greatly reduce the concern associated with the routine practice of lime propagation by seed. Although, in our experiments, WBDL phytoplasma was not transmitted through the seed of infected lime, seedlings derived from such seed were less vigorous. Therefore, planting of seed derived from healthy trees may still be of benefit to growers.

\section{Acknowledgments}

This research was funded in part by Iranian WBDL Management Program and by the Council of the Centers of Excellence.

\section{Literature Cited}

1. Botti, S., and Bertaccini, A. 2006. Phytoplasma infection through seed transmission: further observations. Page 76 in: Proc. 16th Int. Congr. Int.
Organ. Mycoplasmology. R. D. Ayling, C. Citti, and R. A. J. Nicholas, eds. Veterinary Laboratories Agency, Cambridge.

2. Cordova, I., Jones, P., Harrison, N. A., and Oropeza, C. 2003. In situ PCR detection of phytoplasma DNA in embryos from coconut palms with lethal yellowing disease. Mol. Plant Pathol. 4:99-108.

3. Czabator, F. J. 1962. Germination value: an index combining speed and completeness of pine seed germination. For. Sci. 8:386-396.

4. Doyle, J. J., and Doyle, J. L. 1990. Isolation of plant DNA from fresh tissue. Focus 12:13-15.

5. El-Kharbotly, A., Al-Shanfari, A., and Al-Subhi, A. 2000. Molecular evidence for the presence of the $\mathrm{Ca}$. Phytoplasma aurantifolia in lime seeds and transmission to seedlings. Pages 97-98 in: Proc. Int. Soc. Citricult. Orlando, FL.

6. Gundersen, D. E., and Lee, I. M. 1996. Ultrasensitive detection of phytoplasmas by nested-PCR assays using two universal primer pairs. Phytopathol. Mediterr. 35:144-151.

7. Hartman, H. T., Kester, D. E, and Davies, F. T., Jr. 1990. Plant Propagation Principles and Practice. Prentice-Hall International, Inc.

8. Jiang Hua, W. W., Saiki, T., Kawakita, H., Watanabe, K., and Sato, M. 2004. Distribution patterns of mulberry dwarf phytoplasma in reproductive organs, winter buds, and roots of mulberry trees. J. Gen. Plant Pathol. 70:168173.

9. Khan, I. A. 2005. Management and Control of Witches'-Broom Disease of Lime. International Tropical Fruits Workshop (Citrus and Mango).

10. Lee, I. M., Davis, R. E., and Gundersen-Rindal, D. E. 2000. Phytoplasmas: phytopathogenic mollicutes. Annu. Rev. Microbiol. 54:221-255.

11. Lee, I. M., Gundersen-Rindal, D. E., Davis, R. E., and Bartoszyk, I. M. 1998. Revised classification scheme of phytoplasmas based on RFLP analyses of $16 \mathrm{~S}$ rRNA and ribosomal protein gene sequences. Int. J. Syst. Bacteriol. 48:1153-1169.

12. Murashige, T., and Skoog, F. 1962. A revised medium for rapid growth and bioassays with tobacco tissue cultures. Physiol. Plant. 15:473-497.

13. Necas, T., Maskova, V., and Krska, B. 2008. The possibility of ESFY phytoplasma transmission through flowers and seeds. Acta Hortic. 781:443-447.

14. Nipah, J. O., Jones, P., and Dickinson, M. J. 2007. Detection of lethal yellowing phytoplasma in embryos from coconut palms infected with Cape St. Paul wilt Disease in Ghana. Plant Pathol. 56:777-784.

15. Nipah, J. O., Jones, P., Hodgetts, J., and Dickinson, M. 2007. Detection of phytoplasma DNA in embryos from coconut palms in Ghana, and kernels from maize in Peru. Bull. Insectol. 60:385-386.

16. Salehi, M., Firooz, R., and Baradaran, Gh. 2008. New distribution areas of witches'-broom disease of lime in Iran. Proc. 18th Plant Prot. Congr. Iran. Tabriz. University.

17. Salehi, M., Izadpanah, K., and Rahimian, H. 1997. Witches'-broom disease of lime in Sistan, Baluchistan. Iran. J. Plant Pathol. 33:3-4, 76.

18. Salehi M., Izadpanah, K., Siampour, M., Bagheri, A. N., and Faghihi, M. M. 2007. Transmission of 'Candidatus Phytoplasma aurantifolia' to Bakraee (Citrus reticulata hybrid) by feral Hishimonus phycitis leafhoppers in Iran. Plant Dis. 91:466.

19. Salehi, M., Izadpanah, K., and Taghizadeh, M. 2000. A study on host range and possible vector of lime witches'-broom in Iran. Proc. 14th Plant Prot. Congr. Iran. Isfahan. University Technology.

20. Salehi, M., Izadpanah, K., and Taghizadeh, M. 2002. Witches'-broom disease of lime in Iran: new distribution areas, experimental herbaceous hosts and transmission trials. Pages 293-296 in: Proc. 15th Conf. IOCV, Riverside, CA.

21. Salehi, M., Nejat, N., Tvakoli, A. R., and Izadpanah, K. 2005. Reaction of citrus cultivars to 'Candidatus phytoplasma aurantifolia' in Iran. Iran. J. Plant Pathol. 41:147-149.

22. Schneider, B., Seemuller, E., Smart, C. D., and Kirkpatrick, B. C. 1995. Phylogenetic classification of plant pathogenetic mycoplasmalike organisms or phytoplasmas. Pages 369-380 in: Molecular and Diagnostic Procedures in Mycoplasmology, Vol. 1. S. Razin and J. G. Tulley, eds. Academic Press, New York. 